\title{
Neuropeptide GPCRs in neuroendocrinology
}

\author{
Hubert Vaudry ${ }^{1 *}$ and Jae Young Seong ${ }^{2}$ \\ 1 INSERM U982, IRIB, University of Rouen, Mont-Saint-Aignan, France \\ ${ }^{2}$ Korea University, Seoul, South Korea \\ *Correspondence: hubert.vaudry@univ-rouen.fr \\ Edited and reviewed by: \\ Jeff M. P. Holly, University of Bristol, UK
}

Keywords: neuroendocrinology, neuropeptides, biologically active peptides, G protein-coupled receptors, seven-transmembrane domain receptors, heptahelical receptors, signaling mechanisms, transduction pathways

G protein-coupled receptors (GPCRs) represent the single largest family of plasma membrane receptors, encompassing about 860 members in humans. During the last decades, considerable progress has been made regarding the biochemical identification, signaling mechanisms, allosteric modulation, structural characterization, and pathophysiological implication of GPCRs, which are considered as major targets for the development of new therapeutic agents. Thus, in 2012, Robert J. Lefkowitz and Brian K. Kobila shared the Nobel Prize in Chemistry for their seminal contribution on GPCR structures and functions.

Neuropeptides play a pivotal role in chemical communication in the brain and in peripheral organs. To date, more than 100 neuropeptides have been identified and it is established that a vast majority of them act through GPCRs. Neuropeptide GPCRs are involved in the control of a large array of physiological processes including feeding, reproduction, growth, metabolism, stress response, sleep, and a number of behaviors. The aim of this Research Topic is to illustrate the importance of neuropeptide
GPCRs in neuroendocrine communication by gathering a bouquet of 72 review papers and original articles from leading scientists in this fast-evolving field.

We are deeply indebted to all authors who have contributed to this Research Topic and to the dedicated reviewers who helped us reaching the highest quality standards. We gratefully acknowledge the valuable support of the Frontiers team and Mrs Catherine Beau for her invaluable help in the processing of manuscripts.

Received: 11 March 2014; accepted: 19 March 2014; published online: 04 April 2014. Citation: Vaudry H and Seong JY (2014) Neuropeptide GPCRs in neuroendocrinology. Front. Endocrinol. 5:41. doi: 10.3389/fendo.2014.00041

This article was submitted to Neuroendocrine Science, a section of the journal Frontiers in Endocrinology.

Copyright (c) 2014 Vaudry and Seong. This is an open-access article distributed under the terms of the Creative Commons Attribution License (CC BY). The use, distribution or reproduction in other forums is permitted, provided the original author (s) or licensor are credited and that the original publication in this journal is cited, in accordance with accepted academic practice. No use, distribution or reproduction is permitted which does not comply with these terms. 